\title{
15
}

\author{
Across the Great Wall \\ E-commerce Joint Statement Initiative Negotiation and China
}

Henry Gao *

On 13 December 2017, seventy-one members of the World Trade Organization (WTO) led by the USA, European Union (EU) and Japan issued a "Joint Statement on Electronic Commerce" at the 11th WTO Ministerial Conference in Buenos Aires, Argentina. In the Joint Statement, the members announced that they would "initiate exploratory work together toward future WTO negotiations on traderelated aspects of electronic commerce". At the World Economic Forum on 25 January 2019, seventy-six WTO members issued another Joint Statement, which announced their intention to "commence WTO negotiations on trade-related aspects of electronic commerce". The most notable new participant in the second Joint Statement is China, which has so far resisted the electronic commerce initiative.

Why was China reluctant to participate in the e-commerce negotiation at first? Why did it change position in 2019? What will be the main issues in the negotiation? What are the positions of China and how will its participation shape the negotiation? By answering these questions, this chapter provides a critical analysis of the data regulation of China, a world leader in the artificial intelligence (AI) and data-driven economy.

This chapter will proceed in four parts. Section I reviews the development of the Internet and e-commerce in China, as well as China's experiences with e-commerce issues in the WTO and beyond, especially in free trade agreements (FTAs). Section II discusses the history of the e-commerce negotiations in the WTO, from the 1998 e-commerce Declaration and the Doha Declaration to the Joint Statement in 2017 and the launch of the plurilateral Joint Statement Initiative (JSI) negotiations in 2019, with China joining at the last minute. Section III analyses in detail China's three submissions in the negotiations, as well as the most problematic issues for China. In Section IV, the chapter concludes with reflections on how the

This research is supported by the National Research Foundation, Singapore under its Emerging Areas Research Projects (EARP) Funding Initiative. Any opinions, findings and conclusions or recommendations expressed in this material are those of the author(s) and do not reflect the views of National Research Foundation, Singapore. All data in the paper are current as of 2 April 2021. 
negotiations will unfold, especially how the main sticking points in China's Internet and data regulatory regime could be addressed.

\section{CHINA AND E-COMMERCE}

"Across the Great Wall we can reach every corner of the world". Such is the prescient message in the very first email from China, sent on 20 September 1987 by a group of researchers at the Institute for Computer Science of China's State Commission of Machine Industry to the University of Karlsruhe in Germany. ${ }^{1}$ However, it was not until 20 April 1994 that the first connection to the international network was established by the China Education and Research Network, which marked the launch of the Internet in China. ${ }^{2}$

Since then, the Chinese Internet has grown by leaps and bounds, despite occasional hiccups such as Google's exit from China in 2009. ${ }^{3}$ In 2013, China's e-commerce volume exceeded 10 trillion RMB and it overtook the USA as the largest e-commerce market in the world. ${ }^{4}$ Nowadays, Chinese e-commerce giants like Alibaba are among the biggest online retailers in the world and Chinese online shopping festivals such as the Singles Day (11.11) Sale have gained loyal followings all around the world. ${ }^{5}$

Notwithstanding the phenomenal growth in the e-commerce sector, the Internet remains under tight regulation in China. ${ }^{6}$ This started with hardware regulations in the early days of the Chinese Internet, which required that all internet connections must go through official gateways sanctioned by the Chinese government. Then the government moved to software regulation and started to require that software used for internet access must be sanctioned by the government. The latest iteration is content and data regulation, which culminated in the introduction of Cybersecurity Law in 2016, elevating internet regulation to a matter of national security.

1 W Li, "In the Beginning ..." (China Daily, 17 March 2008), https:/perma.cc/VG6T-CBXT.

2 Guowuyuan Xinwen Bangongshi [State Council Information Office] “《中国互联网状况》白皮书 [China's White Paper on the State of the Internet]" (SCIO, 8 June 2010), www.scio.gov.cn/tt/ Document/1011194/1011194.htm.

3 For a review of the background of the case and the trade law issues it raised, see H Gao, "Google's China Problem: A Case Study on Trade, Technology and Human Rights Under the GATS" (2011) 6 Asian Journal of WTO \& International Health Law and Policy 347, at 347-385.

4 “我国大宗电子商务交易额已超10万亿元 [China’s Bulk E-commerce Transaction Value Exceeds 10 Trillion]" (Zhongguo Caijing Bao [China Financial and Economic News], 7 August 2014), https:// perma.cc/3ZCE-P4MX. See also “中国电子商务报告 (2013) [China E-commerce Report of 2013]” (MOFCOM, 23 September 2014), https://perma.cc/UB9Y-C3YA.

5 See M Smith, “Australian Brands Woo Shoppers at China's Singles' Day Sales” (Financial Review, 12 November 2018), https://perma.cc/V3KA-9UBE; J Lim, "Singles' Day Sales in S[inga]pore Doubled from a Year Before: ShopBack's Data” (Today Singapore, 12 November 2018), www.todayonline.com /singapore/singles-day-sales-spore-doubled-year-shopbacks-data.

6 For a detailed analysis of the evolution of internet regulation in China, see H Gao, "Data Regulation with Chinese Characteristics", in M Burri (ed.), Big Data and Global Trade Law (Cambridge, Cambridge University Press, 2021), at 245-267, https://ssrn.com/abstract $=3430284$. 
Internationally, China has engaged with e-commerce regulation at both the multilateral and regional levels. In the WTO, China's first encounter with data regulation started on the wrong foot as it concerned a sensitive area: China's regulation of publications and audio-visual products. ${ }^{7}$ In that case, the USA complained that China had failed to grant foreign firms the right to import and distribute publication and audio-visual products. One of the key issues in the case is whether China's commitments on "sound recording distribution services" covers "electronic distribution of sound recordings" as alleged by the USA. ${ }^{8}$ China disagreed with the US approach and argued instead that such electronic distribution "in fact corresponds to network music services", ${ }^{9}$ which only emerged in 2001 and were totally different in kind from the "sound recording distribution services". According to China, the most fundamental difference between the two is that, unlike "traditional" sound recording distribution services, network music services "do not supply the users with sound recordings in physical form, but supply them with the right to use a musical content". ${ }^{10}$ In response, the USA cited the panel's statement in USGambling" that "the GATS [General Agreement on Trade in Services] does not limit the various technologically possible means of delivery under mode 1 ", as well as the principle of "technological neutrality" mentioned in the Work Programme on Electronic Commerce - Progress Report to the General Council, ${ }^{12}$ and argued that electronic distribution is merely a means of delivery rather than a new type of service. ${ }^{13}$ Furthermore, the USA argued that the term "distribution" encompasses not only the distribution of goods, but also distribution of services. ${ }^{14}$ After a lengthy discussion canvassing the ordinary meaning, the context, the provisions of the GATS, the object and purpose and various supplementary means of interpretation, the panel concluded that the term "sound recording distribution services" does extend to distribution of sound recording through electronic means. ${ }^{15}$ China appealed the panel's findings, but they were upheld by the Appellate Body, which largely adopted the panel's reasoning. ${ }^{16}$

7 Panel Report, China - Measures Affecting Trading Rights and Distribution Services for Certain Publications and Audiovisual Entertainment Products, WT/DS $6_{3} 6_{3} / \mathrm{R}$ and Corr.1, adopted 19 January 2010, as modified by Appellate Body Report WT/DS $363 / \mathrm{AB} / \mathrm{R}, \mathrm{DSR} 2010: \mathrm{II}, 261$ [hereinafter Panel Report: China - Publications and Audiovisual Products].

8 Ibid., at paras. 4.49-4.71.

9 Ibid., at para. 4.147.

10 Ibid., at para. 4.149.

11 Panel Report, United States - Measures Affecting the Cross-Border Supply of Gambling and Betting Services, WT/DS285/R, adopted 20 April 2005, as modified by Appellate Body Report, WT/DS285/AB/ R, DSR 2005:XII, 5797 .

12 Work Programme on Electronic Commerce, Progress Report to the General Council, adopted by the 230 Council for the Trade in Services on 19 July 1999, S/L/74, circulated 27 July 1999, at para. 4.

13 Ibid., at para. 4.69.

14 Ibid., at para. 7.1156.

15 Ibid., at paras. 7.1168-1265.

16 Appellate Body Report, China - Measures Affecting Trading Rights and Distribution Services for Certain Publications and Audiovisual Entertainment Products, WT/DS ${ }_{3} 6_{3} / \mathrm{AB} / \mathrm{R}$, adopted 
The case was also the first WTO case concerning China's censorship regime. It is interesting to note, however, that the USA did not challenge the censorship regime per se. ${ }^{17}$ Instead, the USA only challenged the alleged discrimination in the operation of the regime, where imported products were subject to more burdensome content review requirements. ${ }^{18}$ Ironically, the USA even proposed, as the solution to the alleged discrimination, that the Chinese government itself should shoulder the sole responsibility for conducting content review, rather than outsourcing it to importing firms. ${ }^{19}$

With such an unpleasant experience, China took a cautious approach on the inclusion of internet or data regulation in other forums, such as FTAs. While it has signed more than a dozen FTAs so far, most of them have not included provisions on such regulations. Until China signed the Regional Comprehensive Economic Partnership (RCEP) in November 2020, the only ones with included stand-alone chapters on e-commerce are the two FTAs China signed with Korea and Australia in $2015,{ }^{20}$ the FTA signed with Mauritius and Cambodia in 2019 and in 2020, respectively, as well as the recently upgraded FTAs with Chile ${ }^{21}$ and Singapore. ${ }^{22}$ However, unlike the US FTAs, which often include provisions on free flow of data and bans on data localization requirements, ${ }^{23}$ these six pre-RCEP FTA chapters only address e-commerce-related issues such as a moratorium on customs duties on electronic transmission; electronic authentication and electronic signatures; protection of personal information in e-commerce; and paperless trading. ${ }^{24}$

Over the past five years, capitalizing on the enormous success of the Chinese e-commerce market, China has been pushing for wider adoption of its e-commerce model beyond its own shore. At the regional level, China has been building the electronic silk road, which provides online e-commerce platforms to facilitate both the exports of Chinese products abroad and the imports of foreign products into

19 January 2010, DSR 2010:I, 3, at paras. 338-413 [hereinafter ABR, China - Publications and Audiovisual Products].

17 Ibid., at para. 20.

18 Panel Report: China - Publications and Audiovisual Products, note 7 above, paras. 4.72-4.85.

19 Ibid., at para. 7.875; ABR, China - Publications and Audiovisual Products, note 16 above, at para. 72.

20 See H Gao, "E-Commerce in ChAFTA: New Wine in Old Wineskins?", in C Piker et al. (eds), The China Australia Free Trade Agreement: A 21st-Century Model (Oxford, Hart Publishing, 2018).

${ }_{21}^{21}$ "Protocol to Amend the Free Trade Agreement and the Supplementary Agreement on Trade in Services of the Free Trade Agreement between the Government of the People's Republic of China and the Government of the Republic of Chile" (2017), https://perma.cc/8PGG-HNVF, at chapter 4.

22 "Protocol to Upgrade the Free Trade Agreement between the Government of the People's Republic of China and the Government of the Republic of Singapore" (2018), https:/perma.cc/8DKV-UUB8, at appendix 6, new chapter 15 .

23 See H Gao, "Regulation of Digital Trade in US Free Trade Agreements: From Trade Regulation to Digital Regulation" (2018) 45 Legal Issues of Economic Integration 47; M Wu, "Digital Trade Related Provisions in Regional Trade Agreements: Existing Models and Lessons for the Multilateral Trade System" (2017), RTA Exchange, https://perma.cc/C2JJ-UKWP; RF Fefer et al., "Digital Trade and U.S. Trade Policy" (2019), CRS Report for Congress R44565, https://perma.cc/SHH7-7MKF.

24 See H Gao, "Digital or Trade? The Contrasting Approaches of China and US to Digital Trade" (2018) 21 Journal of International Economic Law 297. 
China. ${ }^{25}$ At the multilateral level, Alibaba, with the support of the Chinese government, has been aggressively promoting its Electronic World Trade Platform (eWTP) concept, which led to the launch of the "Enabling e-commerce" initiative along with the WTO and the World Economic Forum in late 2017. ${ }^{26}$ As discussed later in the chapter, these initiatives have also found their way into China's e-commerce proposals in the JSI.

\section{CHINA AND THE JOINT STATEMENT INITIATIVE: RESISTANCE} AND ACCEPTANCE

Recognizing the growing importance of e-commerce, WTO members adopted the Declaration on Global Electronic Commerce at the second Ministerial Conference in $1998 .{ }^{27}$ In addition to establishing a temporary moratorium on customs duties on digital transmission, the Declaration also calls on WTO members to "examine all trade-related issues relating to global electronic commerce". Pursuant to the Declaration, the General Council adopted the Work Programme on Electronic Commerce, ${ }^{28}$ which divided up the work among several WTO bodies such as the Council for Trade in Services, the Council for Trade in Goods, the Council for Trade-Related Aspects of Intellectual Property Rights and the Committee on Trade and Development. While the division of work among the different bodies provided an opportunity for in-depth discussions on the impact of e-commerce in different areas, such a compartmentalized approach was not really conducive to the negotiations because of the inherent complexity of e-commerce, which does not fit neatly into the pigeonholes of goods, service and intellectual property rights. Thus, by July 1999, the bodies had reached an impasse in their respective discussions and the discussions were suspended.

As WTO members started to grasp the cross-cutting nature of e-commerce issues, the General Council decided on 8 May 2001 to have dedicated sessions to discussions cross-cutting issues in e-commerce, with the first held on 15 June 2001. ${ }^{29}$ Since then, a total of twelve dedicated session have been held, with the last one on 18 October $2016 .{ }^{30}$ However, other than agreeing to continue the moratorium on customs duties on electronic transmission periodically, these cross-cutting discussions have failed to produce substantive results and the members remain divided on

25 “跨境电商连接网上丝绸之路 [Cross-Border E-commerce Connects Cyber Silk Road]” (People's Daily, 12 June 2018), https:/perma.cc/K4 $\mathrm{H}_{9}-\mathrm{A}_{47} \mathrm{U}$.

26 See Gao, note 24 above, at 308-310.

27 WTO, Declaration on Global Electronic Commerce, adopted on 20 May 1998 at the Second WTO Ministerial Conference in Geneva, WT/MIN(98)/DEC/2, 25 May 1998.

28 WTO, Work Programme on Electronic Commerce: Ministerial Decision of 13 December 2017 , Ministerial Conference, Eleventh Session, Buenos Aires, 10-13 December 2017, WT/MIN(17)/65, WT/L/1032, 18 December 2017.

29 Dedicated Discussion on Electronic Commerce under the Auspices of the General Council on 15 June 2001, Summary by the Secretariat of the Issues Raised, WT/GC/W/436, 6 July 2001.

30 "Electronic Commerce" (WTO), https://perma.cc/7ZKN-KVSD. 
even the most basic issues such as the mode of supply and classification of e-commerce. Indeed, the division among the members was so wide that no substantive discussion was held at the twelfth dedicated session because of the procedural concerns raised by some members. ${ }^{31}$ Because of the opposition, discussions have only been held in informal, open-ended meetings convened by the General Council Chair since then and the process has basically stalled.

In view of the lack of progress under the formal Work Programme, the proponents of the e-commerce negotiation started to explore alternative ways to advance the negotiation. This was recognized by the Ministerial Declaration at the Nairobi Ministerial Conference in December 2015, which acknowledged that some members "believe new approaches are necessary to achieve meaningful outcomes in multilateral negotiations". ${ }^{22}$ The USA was even more explicit in its statement, with the then United States Trade Representative (USTR) Michael Froman declaring the Nairobi Ministerial would begin "the road to a new era for the WTO" and stating that "[a]s WTO members start work next year, they will be freed to consider new approaches to pressing unresolved issues and begin evaluating new issues for the organization to consider". 33

After Nairobi, e-commerce gained "renewed interest" among WTO members. ${ }^{34}$ On 1 July 2016, the first post-Nairobi submission was made by the USA. Likely in anticipation of the strong resistance from developing countries, the USA took a rather cautious approach and labelled its submission a "non-paper" that is "intended solely to contribute to constructive discussion among Members" rather than to advance "specific negotiating proposals". ${ }^{35}$ While the non-paper repeatedly emphasizes that the USA has "no preconceived views on best approaches, or on whether negotiations on specific aspects of e-commerce should be pursued, and if so on what bases", ${ }^{6}$ many of the examples raised in the paper reiterated the US proposals in the negotiations of the Trade in Services Agreement (TiSA) and TransPacific Partnership Agreement (TPP) and brought into the WTO new issues such as free flow of data, bans on data localization and forced transfer of source code for the first time. ${ }^{37}$

The US submission spurred a new wave of activity from other members, with major players such as Japan, the EU, Brazil, Canada and Singapore all making

${ }^{31}$ General Council, 7 December 2016, Item 6 - Work Programme on Electronic Commerce: Progress Report by the Chairman, WT/GC/W/728, 8 December 2016.

32 "Nairobi Ministerial Declaration" (WTO), https://perma.cc/3NP6-YGUF, at para. 30.

33 "Statement by Ambassador Michael Froman at the Conclusion of the 1oth World Trade Organization Ministerial Conference" (Office of the United States Trade Representative (USTR), 19 December 2015), https://perma.cc/JAN3-2EE9.

34 WTO General Council, "Item 4 - Work Program on Electronic Commerce - Review of Progress: Report by Ambassador Alfredo Suescum - Friend of the Chair", WT/GC/W/721, 1 August 2016.

35 WTO, Work Program on Electronic Commerce: Non-paper from the United States, JOB/GC/94, 4 July 2016 , at para. 1.3.

${ }^{6}$ Ibid., at para. 1.2.

37 Gao, note 24 above, at 307-308. 
submissions within the same month. ${ }^{3}$ The work intensified over the next sixteen months, and at the 11th Ministerial Conference held in December 2017 in Buenos Aires, seventy-one members led by three co-conveners - Australia, Japan and Singapore - launched a joint statement to "initiate exploratory work together toward future WTO negotiations” on e-commerce. ${ }^{39}$ Nine meetings were held in 2018 , and the negotiations were finally launched by seventy-six members at the side-lines of the World Economic Forum Annual Meeting in Davos on 25 January 2019. ${ }^{\circ}$

Initially, China was quite reluctant to support the launch of e-commerce negotiations. In its first submission on e-commerce at the WTO, China tried to pre-empt the upcoming e-commerce negotiation in several ways. ${ }^{41}$ First, reflecting its longstanding position that only goods-related e-commerce issues should be discussed, China proposed, at the outset, that the scope of e-commerce discussions should "focus on promotion and facilitation of cross-border trade in goods enabled by internet, together with services directly supporting such trade in goods, such as payment and logistics services". ${ }^{42}$ Second, China also indicated that it was not ready to negotiate new rules for e-commerce by stating that e-commerce discussions are "to clarify and to improve the application of existing multilateral trading rules", which are normally understood not to include issues such as free flow of data, data localization, etc. ${ }^{43}$ Third, China also tried to prevent e-commerce negotiations from being used as a Trojan horse for "new market access commitments including tariff reductions". ${ }^{44}$ By taking out new rules and new tariff concessions, the Chinese submission then spelt out the only issues China might be willing to consider: trade facilitation, transparency, digital certificates, electronic signatures, electronic authentication and consumer protection and privacy. ${ }^{45}$ The same elements were reiterated in China's submission to the General Council and the three subsidiary councils on the General Agreement on Tariffs and Trade (GATT), GATS and Development in October 2017, which deemed these issues as "elements acceptable to Members". ${ }^{6}$

$3^{8} \mathrm{JOB} / \mathrm{GC} / 96$ (Japan et al.); JOB/GC/97 (EU et al.); JOB/GC/98 (Brazil); JOB/GC/99 (MIKTA countries); JOB/GC/100 (Japan); JOB/GC/101/Rev.1 (Singapore et al.).

39 WTO, Joint Statement on Electronic Commerce, Ministerial Conference, Eleventh Session, Buenos Aires, 10-13 December 2017, WT/MIN(17)/6o, 13 December 2017.

$4 \circ$ WTO, Joint Statement on Electronic Commerce, WT/L/1056, 25 January 2019.

${ }^{41}$ WTO General Council, Council for Trade in Goods, Council for Trade in Services, Committee on Trade and Development, Work Programme on Electronic Commerce: Aiming at the 11th Ministerial Conference, Communication from the People's Republic of China and Pakistan, Revision, JOB/GC/ 110/Rev.1, JOB/CTG/2/Rev.1, JOB/SERV/243/Rev.1, JOB/DEV/39/Rev.1, 16 November 2016.

42 Ibid., introduction. For a detailed explanation of the meaning of "trade in goods enabled by internet", see Gao, note 24 above, at 314 .

43 Ibid., introduction.

44 Ibid.

45 See Gao, note 24 above, at 314-315.

46 E-Commerce Elements for MC11, Communication from China, JOB/GC/142, JOB/CTG/9, JOB/ SERV/271, JOB/DEV/49, 19 October 2017. 
Trying to steer the course on e-commerce negotiations at the Ministerial Conference, China even submitted a draft Ministerial Decision on Electronic Commerce, which suggested continuing the work under the Work Programme on Electronic Commerce in the General Council, while raising the possibility of reinvigorating the dedicated discussions on "elements acceptable to Members" such as "facilitating cross-border e-commerce; promoting paperless trading; transparency; as well as development and cooperation". ${ }^{47}$ Most of the draft made its way into the final Ministerial Decision, ${ }^{48}$ prompting Chinese Ministry of Commerce (MOFCOM) Vice Minister Wang Shouwen to boast that "China has become a participant and even leader in rule-making". ${ }^{9}$ However, by abandoning the consensus-based approach and launching the JSI via the plurilateral route, the USA and the other seventy members have turned China's success into a pyrrhic victory.

In a way, the e-commerce Joint Statement caught China by surprise. For China, the most important issue at the 11th Ministerial Conference was investment facilitation, which China has been pushing for at the WTO since 2014 as the coordinator of the group on "friends of investment facilitation for development". ${ }^{\circ}$ Designed to provide support for its Belt and Road Initiative, China successfully persuaded seventy WTO members to co-sponsor a Joint Statement on the issue. ${ }^{51}$ While China was also interested in e-commerce, its main task at the 11th Ministerial Conference was to push the WTO and World Economic Forum to officially endorse the "Enabling e-commerce" initiative - the brainchild of the Alibaba-backed eWTP - a mission that was also accomplished..$^{22}$ In contrast, the e-commerce Joint Statement, as a US-led initiative, made China quite wary.

Thus, many observers were surprised by China's "last-minute" decision to join the 2nd e-commerce Joint Statement on 25 January 2019. ${ }^{53}$ However, a careful reading of the events in 2018 still reveals many hints explaining China's shift. After the 11th Ministerial, the sponsors of the e-commerce Joint Statement did not waste any time in getting to business and held nine meetings over the short span of one year. Such a frenzy of activities was unheard of in the WTO and proves that they are quite

47 Work Programme on Electronic-Commerce, Communication from China, JOB/GC/15o, 10 November 2017.

$4^{8}$ Work Programme on Electronic Commerce, Ministerial Decision of ${ }_{13}$ December 2017, WT/MIN(17)/ 65, WT/L/1032, 18 December 2017.

49 “热点问答: 世贸组织第11届部长级会议中国怎么看 [Hot Questions Q\&A: China's Opinion on the 11th WTO Ministerial Meeting]" (Xinhua News, 14 December 2017), https://perma.cc/GWY9$7 \mathrm{UK} 8$.

50 “Investment Facilitation for Development", https://perma.cc/8LKD-LPCV.

${ }^{51}$ Joint Ministerial Statement on Investment, Facilitation for Development, WT/MIN(17)/59, 13 December 2017.

52 "WTO, World Economic Forum and eWTP Launch Joint Public-Private Dialogue to Open up E-commerce for Small Business" (WTO, 11 December 2017), https://perma.cc/W97H-SQ5F.

53 B Baschuk and S Donnan, "China to Join Talks on \$25 Trillion E-Commerce Market at Last Minute" (Bloomberg, 25 January 2019), https://perma.cc/273Y-EEHK. 
serious. Moreover, the key players in the e-commerce Joint Statement - the USA, the EU and Japan - kept referring to e-commerce in the three trilateral statements on WTO reform they issued in 2018. ${ }^{44}$ In the last one issued in September 2018, they further agreed to "intensify and accelerate this process" to achieve "the timely launch of negotiations of a high standard agreement with the participation of as many members as possible". Three more trilateral statement were issued after 2018 , with the latest one being issued on 14 January 2020. ${ }^{55}$ All these developments reminded China that the e-commerce Joint Statement parties are taking the issue very seriously and China could not just ignore it. Indeed, China learned its lesson the hard way when its attempt to join the TiSA negotiations was blocked by the USA, making it impossible for China to shape the rules on services trade, where e-commerce was a major issue. ${ }^{56}$ The first indication of the policy change can be detected when China released its position paper on WTO reform on 23 November 2018.57 While the position paper took the cautious approach and did not explicitly mention e-commerce, at the press conference held on the same day, Vice Minister Wang made a direct reference to e-commerce in response to a question from a journalist for examples on how to "keep the WTO rules relevant", a key objective for China in WTO reform..$^{8}$

After China joined the 2nd e-commerce Joint Statement on 25 January 2019, Chinese WTO Ambassador Dr Zhang Xiangchen also gave an official explanation for the shift in position. ${ }^{59}$ First, referring to the critical juncture the WTO was at, Zhang pointed to the special significance the launch of the e-commerce negotiation could have in reinvigorating the negotiation function of the WTO and boosting people's confidence in the multilateral trading system and economic globalization. Second, Zhang also regarded China's participation as a good opportunity for it to play an active role in the negotiations, especially in reflecting the participation of

54 The three statements are: "Joint Readout from Meeting of the United States, European Union and Japan in Brussels" (USTR, 10 March 2018), https://perma.cc/9WUC-S7MU; "Joint Statement on Trilateral Meeting of the Trade Ministers of the United States, Japan, and the European Union" (USTR, 31 May 2018), https://perma.cc/UG6U-GDHV; "Joint Statement on Trilateral Meeting of the Trade Ministers of the United States, Japan, and the European Union” (USTR, 25 September 2018), https://perma.cc/ZL3Q-UTEL.

55 The three statements are: "Joint Statement of the Trilateral Meeting of the Trade Ministers of the European Union, Japan and the United States" (USTR, 9 January 2019), https://perma.cc/D9PSUWS5; "Joint Statement of the Trilateral Meeting of the Trade Ministers of the United States, European Union, and Japan" (USTR, 23 May 2019), https://perma.cc/LGD4-GDP2; "Joint Statement of the Trilateral Meeting of the Trade Ministers of Japan, the United States and the European Union" (USTR, 14 January 2020), https://perma.cc/43M8-VYLC.

56 Gao, note 24 above, 301-304.

$57 \mathrm{MOFCOM}$, “中国关于世贸组织改革的立场文件 [China's Position Paper on WTO Reform]”, https://perma.cc/ $\mathrm{K}_{9} \mathrm{~S}_{4}-\mathrm{JN}_{2} \mathrm{~F}$.

58 “商务部召开世贸组织改革有关问题新闻吹风会 [China's Ministry of Commerce Opens News Conference for Response to WTO-Related Reforms]" (PRC Gov, 23 November 2018), https:/perma .cc/RS6E-C $32 \mathrm{Q}$.

59 “世贸组织成员在达沃斯签署电子商务联合声明 [WTO Members Sign Joint Statement on E-commerce at Davos]" (Xinhua News, 25 January 2019), https://perma.cc/CT5U-4L9J. 
developing countries and designing a flexible framework to reflect the reasonable demands of different parties.

For long-time observers of China's trade policy, such shifts in position are not unprecedented. For example, in the early stages of the Doha Round negotiations, China sided with developing countries. Before the Cancun Ministerial Conference in September 2003, China and sixteen other developing countries formed the "Core Group", which resisted the push by the "Colorado Group" of developed countries to start negotiations on the Singapore issues including trade facilitation. ${ }^{6 \circ}$ However, when the General Council decided to start negotiations on trade facilitations on 1 August 2004, China became an active participant. ${ }^{61}$ This makes sense because China, as one of the top exporters in the world, would benefit from more efficient and cheaper customs processes. ${ }^{62}$ Like trade facilitation, China's decision to join the e-commerce negotiations demonstrated once again its flexibility when it comes to specific trade issues and its willingness "to take up commitments commensurate with its level of development and economic capability", as stated in its position paper on WTO reform. ${ }^{63}$

\section{THE CHINESE PROPOSALS}

From an initial group of seventy-six members in January 2019, the JSI has grown to include eighty-six members as of 1 April 2021, with Ecuador the newest participant. Together, they represent more than 90 per cent of global trade and over half of the WTO's membership. In addition, the JSI also remains open for participation by nonmembers, which include Senegal, the LDC signatory of the Osaka Declaration on e-commerce, which has yet to join the JSI as a formal member. ${ }^{64}$

Before January 2019, the JSI was framed around four themes: (1) enabling digital trade/e-commerce; (2) openness and digital trade/e-commerce; (3) trust and digital trade/e-commerce; and (4) cross-cutting issues, including development, transparency and cooperation. ${ }^{65}$ During the exploratory discussions held in 2018 , each theme was further divided into several sub-themes, resulting in thirteen subthemes in total. Selected issues and topics were further identified under each subtheme, resulting in over forty issues in total. ${ }^{66}$

Z Sun (ed.), WTO多哈回合谈判中期回顾 [Mid-Term Review of the WTO Doha Round Negotiations] (Beijing, People's Publishing House [Renmin Chubanshe] 2005), at 178-181.

61 Ibid., 194-195.

62 H. Gao, "China's Ascent in Global Trade Governance: From Rule Taker to Rule Shaker, and Maybe Rule Maker?”, in C. Deere-Birkbeck (ed.), Making Global Trade Governance Work for Development (Cambridge, Cambridge University Press, 2001), at 166.

63 MOFCOM, note 57 above, at 4 .

64 IDEAS, "WTO Joint Statement on Electronic Commerce: Advancing the Search for Convergence" (IDEAS), https://perma.cc/6EQJ-YTHY.

65 Ibid.

66 Ibid. 
Since January 2019, the group has moved on to the plurilateral negotiations phase and the themes were also expanded to include two new ones: (5) telecommunications; and (6) market access. ${ }^{67}$ The six themes were further divided into fifteen subthemes and thirty-five selected issues/topics. ${ }^{68}$ In the negotiation process, China has emerged as one of the most active participants with four submissions out of a total of fifty-two substantive submissions so far. ${ }^{69}$ As China's last submission is restricted and only has one page, ${ }^{70}$ this section will examine the first three submissions, which provide a detailed account of China's position.

\section{A The First Submission}

The first submission was submitted by China on 23 April $2019^{71}$ and reiterated its general positions made on prior occasions leading to China's participation in the JSI. The first part sets out China's overall approach to the JSI negotiation, which covers four areas: the objective, the relationship with the WTO, the negotiation process, and its direction and focus. It started by noting that development should be the objective of the JSI and calling on participates to help "Members, particularly developing Members and LDCs, to integrate into global value chains, bridge the digital divide, seize development opportunities and benefit from inclusive trade, and hence better participating in the economic globalization". Consistent with the developing country position, China also stated that the JSI negotiation "should be complementary to the electronic commerce discussion in relevant subsidiary bodies of the WTO" and "ultimately achieve a multilateral outcome". This approach is also reflected in China's proposal for the negotiation process, where it noted that the JSI negotiation "should be open, inclusive and transparent" with "well-designed frameworks and flexible approaches on the implementation of negotiation outcomes". This point probably reflects China's unhappy experience with the TiSA negotiations, when the USA reportedly blocked its request to participate in the closed, exclusive and nontransparent negotiation. The mentioning of "flexible approaches on the implementation of negotiation outcomes", on the other hand, indicates that China might not accept all obligations but prefers a tiered approach on commitments, which again

67 Ibid.

68 Ibid.

69 A search on WTO's Documents Online system on 1 April 2021 using the document symbol for the e-commerce JSI "INF/ECOM/**" generated seventy submissions, but four of them are consolidated or stockpile texts; six of them are revisions or addenda to original submissions, while the other eight are just communications from new participants informing their decisions to participate, which include, for example, INF/ECOM/18 by Benin; INF/ECOM/37 by Kenya; INF/ECOM/38 by Côte D'Ivoire; $\mathrm{INF} / \mathrm{ECOM} / 48$ by Cameroon; INF/ECOM/50 by the Philippines; INF/ECOM/53 by Burkina Faso; INF/ECOM/56 by Guatemala; INF/ECOM/56 by Ecuador.

70 Joint Statement on Electronic Commerce, Communication from China, INF/ECOM/6o, 28 October 2020 .

${ }^{71}$ Joint Statement on Electronic Commerce, Communication from China, INF/ECOM/19, 24 April 2019. 
affirms its willingness to "take up commitments commensurate with its level of development and economic capability". ${ }^{72}$ With regard to the scope of the JSI negotiation, China further emphasized that it should "focus on the discussion of cross-border trade in goods enabled by the internet, together with relevant payment and logistics services while paying attention to the digitalization trend of trade in services, and explore the way to develop international rules for electronic commerce centering on a sound transaction environment and a safe and trust-worthy market environment." This is again unsurprising given China's strong interests in trade in goods and the relevant trade facilitation and electronic payment issues, ${ }^{73}$ as evidenced by the enormous success of its homegrown e-commerce model with Alibaba as the e-commerce platform, Alipay as the payment gateway and the many courier services companies as distributors of goods.

The next four subsections further elaborate the focus of the negotiation by listing China's priority issues, which are grouped into four action areas.

\section{Definition and Clarification}

China calls on members to define terms such as trade-related aspects of electronic commerce and electronic transmission, and to clarify the relationship between future electronic commerce rules and existing WTO Agreements.

Both tasks appear innocuous, but as the history of the e-commerce Work Programme has shown, even such mundane discussions could become contentious, especially given the open hostility some WTO members have displayed towards the JSI. Thus, it seems that the more sensible approach is to adopt the "constructive ambiguity" approach and leave these issues undisturbed.

\section{Trade Facilitation Measures}

China also calls on members to "establish a sound environment for electronic commerce transaction", which includes two types of measures. The first are measures to facilitate customs process, such as the improvement of customs procedures, electronic payment of customs fees and electronic customs documentation, establishment of free zones and customs warehouses, and a moratorium on customs duties. The second is mainly the establishment of the necessary legal framework to enable the recognition of electronic signatures, electronic authentication and electronic contracts.

These measures are mostly uncontroversial as they largely copy from the provisions under the Agreement on Trade Facilitation, of which China is a main proponent. The only exception is the moratorium on customs duties on e-commerce, which

72 MOFCOM, note 57 above, at 4.

73 Gao, note 24 above. 
became a contentious issue in 2019 because of the opposition of India and South Africa to extend. ${ }^{74}$ While a decision to extend the moratorium until the 12th Ministerial Conference was finally made by the General Council on 10 December 2019, there is still a possibility for the revocation of the moratorium because of the growing interest among WTO members in collecting tax on digital services and e-commerce. Thus, instead of a permanent moratorium, China only suggested to maintain the practice "until the next Ministerial Conference". This implies that China has yet to decide where its interests lie on the issue and wants to have more time to study the issue.

\section{Safety and Security}

This part of the submission focuses on measures to "create a safe and trust-worthy market environment for electronic commerce", which mainly includes consumer safety regulations, such as measures for online consumer protection, personal information protection and fighting spam or unsolicited electronic commercial messages. Interestingly, the submission also includes a paragraph on "cyber security", which, in addition to language on enhancing e-commerce security and safeguarding cyber security, also calls on members to "respect the Internet sovereignty".

As I discussed in another paper, "Internet sovereignty" has been a favourite slogan for the Chinese government, which elevated internet regulation to the level of national security or even sovereignty to justify its draconian laws. ${ }^{75}$ As shown by the latter parts of the submission discussed next, the reference to "Internet sovereignty" is more than empty propaganda; it does reflect the seriousness China attaches to certain issues and is indicative of China's position on these issues.

\section{Development}

The submission also encourages members to "promote pragmatic and inclusive development cooperation", including measures to help developing countries to improve the e-commerce infrastructure and bridge the digital divide, to share best practices on e-commerce development and help them build up their capacity, and also to "establish an Electronic Commerce for Development Program under the WTO framework".

These initiatives, if successfully implemented, will definitely help developing countries to boost their e-commerce development, which, in turn, could also facilitate the expansion of Chinese e-commerce giants like Alibaba in these countries, especially in regions covered by the Belt and Road Initiative.

74 B Reinsch et al., "Ongoing Goings On: A News Update on WTO" (2020), https://perma.cc/ZQ5Q$\mathrm{V}_{5} \mathrm{PD}$.

75 Gao, note 6 above. 
In the final part titled "Other Issues", China also discussed the main demands of the USA in the JSI; that is, data flow, data storage, treatment of digital products, etc. By addressing them directly and acknowledging them as issues of concern for some members, China has broken from its traditional approach of simply ignoring them. This itself is a positive sign, as it indicates China's willingness to engage on these issues.

At the same time, China also indicated that it was not ready to discuss these issues, at least not in the early stages of the negotiation. Citing the "complexity and sensitivity" of these issues, as well as "the vastly divergent views among the Members", China stated that "more exploratory discussions are needed before bringing such issues to the WTO negotiation, so as to allow Members to fully understand their implications and impacts, as well as related challenges and opportunities". Such an approach is all too familiar to those who follow WTO negotiations closely, as it is basically a polite way of saying "we don't want to discuss these issues now".

In particular, China singled out the issue of cross-border data flow, by stating that "[i]t's undeniable that trade-related aspects of data flow are of great importance to trade development". It is interesting to note, however, what China did and did not say in this sentence. It did not, for example, use "free flow of data", which is how the USA has always referred to the issue in its submissions. ${ }^{76}$ On the other hand, it qualified "data flow" with "trade-related aspects". This implies that China is not willing to address all kinds of data flows, just those related to trade. In other words, to the extent that some data flows do not have a trade nexus, they could be legitimately excluded. This qualification could have wide implications as it could be employed to justify restrictions on data flows in sectors where China has not made a commitment, ${ }^{77}$ or even for those covered by existing commitments but are provided free of charge (such as Google's search engine services) as they are not technically "traded".

Moreover, in an effort to turn the table, China also prefaced the discussion on these "other issues" with the affirmation of "the legitimate right" by members "to adopt regulatory measures in order to achieve reasonable public policy objectives". This language is reminiscent of the calls for more "policy space", a term often employed in trade negotiations to justify special and differential treatment and resort to exceptions clauses. As the China - Publications and Audiovisual case mentioned earlier illustrated, China will, most likely, invoke the public order exception contained in the General Exceptions clauses of both the GATT and GATS to justify its online censorship regime. In particular, on data flow, China emphasized that it

$7^{6}$ See Work Programme on Electronic Commerce, Non-paper from the United States, JOB/GC/94, which refers to "free flow of information" in para. 2.3; and Joint Statement on Electronic Commerce Initiative, Communication from the United States, INF/ECOM/5, which refers to "free flows of information" in section 2.

77 Gao, note 3 above. 
"should be subject to the precondition of security", ${ }^{8}$ and should "flow orderly in compliance with Members' respective laws and regulations". ${ }^{79}$ This extends China's domestic narrative of cybersecurity to the international level, which is made complete with the earlier reference for all members to "respect the Internet sovereignty" of other members. By elevating the issue to one of "sovereignty", China has shown the seriousness it attaches to the issue of regulating data flow.

In summary, China has made it clear that it is not yet ready to discuss these sensitive issues, at least not in the early stages of the negotiations. There is a possibility that it will consider some of the issues further down the road, but such negotiations will not be easy given China's guarded position on these issues.

\section{B The Second Submission}

In its second submission dated 8 May 2019, ${ }^{8 \circ}$ China spelt out its detailed proposals on its priority issues. As China's first substantive proposal, the twelve draft articles in the submission largely corresponds to three of the four main action areas mentioned in section 3 of its first submission; that is, section 3.1 on definition and clarification, section 3.2 on trade facilitation and section 3.3 on safety and security.

The first draft article is titled "scope", but actually dealt with the definition issue by proposing that the agreement "apply to measures affecting the production, distribution, marketing, sale or delivery of goods and services by electronic means". This language copies verbatim the language from the 1998 e-commerce declaration $^{81}$ and confirms China's position that the JSI should "support the multilateral trading system" and "keep WTO rules relevant". In the alternative, China suggests that the agreement "apply to measures adopted or maintained by Members that affect trade by electronic means", which mirrors the language in its FTAs. $^{82}$

The next draft article addresses the relationship with existing WTO Agreements by noting first that in the event of conflicts between the new agreement and the WTO Agreements, those in Annex 1 to the Marrakesh Agreement shall prevail. The next paragraph explicitly states that the new agreement "shall not be construed to have changed or modified Members' market access commitments made under the [GATT or GATS]". This partly reflects China's sour experience in the ChinaPublications case discussed earlier, where the USA used the technology neutrality principle to persuade the panel that China's services schedule also includes commitments on electronic distribution of audio-visual products. Thus, this article was

$7^{8}$ Communication from China, note 71 above, at para. $4 \cdot 3$.

79 Ibid.

8० Joint Statement on Electronic Commerce, Communication from China, INF/ECOM/32, 9 May 2019.

81 Work Programme on Electronic Commerce, WT/L/274, adopted by the General Council on 25 September 1998.

82 China-Singapore Free Trade Agreement (CSFTA), in chapter 15 at Art. 2.2. 
proposed in an attempt to seal the loophole and ensure that China would not inadvertently modify its commitments by participating in the JSI.

The third draft article deals with exceptions, and starts by explicitly noting that Article XX of the GATT 1994 and Article XIV of the GATS "shall apply to this Agreement to the extent applicable" and their provisions "shall be incorporated into and made an integral part of this Agreement, mutatis mutandis". Again, like the previous article, this provision is partly the result of the hard lessons China has learned in the China-Raw Materials ${ }^{8}$ and China-Rare Earth ${ }^{84}$ cases, where because of the lack of explicit reference to the general exception clause of the GATT, China was denied the right to justify its export restrictions under GATT Article XX. In addition, China also specifically pointed out that the new agreement

shall not prevent Members from adopting or maintaining any measures for the purposes of guaranteeing cybersecurity, safeguarding cyberspace sovereignty, protecting the lawful rights and interests of its citizens, juridical persons and other organizations and achieving other legitimate public policy objectives, provided that such measures are not applied in a manner which would constitute a means of arbitrary or unjustifiable discrimination or a disguised restriction on trade, and are no more than necessary to achieve the objectives.

This strong language confirms once again China's obsession with cybersecurity, which is elevated to the level of sovereignty and thus non-negotiable. The second part of the article focuses on "Security Exceptions", where China proposes that the agreement shall not be construed "to require any Member to furnish any information, the disclosure of which it considers contrary to its essential security interests" or "to prevent any Member from taking any action which it considers necessary for the protection of its essential security interest". Again, it is probably not unreasonable to surmise that cybersecurity would be considered a matter of "essential security interest".

The rest of the proposals are mostly unexciting, as they either deal with the issue of trade facilitation, with four articles on electronic authentication and electronic signatures, electronic contracts, electronic invoices and maintaining domestic legal frameworks governing electronic transactions; or the issue of e-commerce safety, with three clauses on unsolicited commercial electronic messages, personal information protection and online consumer protection. Then there are two articles on good governance, with one focusing on transparency and calls for publication of

83 Panel Reports, China - Measures Related to the Exportation of Various Raw Materials, WT/DS $394 / \mathrm{R}$, Add.1 and Corr.1 / WT/DS395/R, Add.1 and Corr.1 / WT/DS398/R, Add.1 and Corr.1, adopted 22 February 2012, as modified by Appellate Body Reports WT/DS $394 / \mathrm{AB} / \mathrm{R} / \mathrm{WT} / \mathrm{DS}_{395} / \mathrm{AB} / \mathrm{R} /$ WT/DS 398/AB/R, DSR 2012:VII, at 3501 .

84 Panel Reports, China - Measures Related to the Exportation of Rare Earths, Tungsten, and

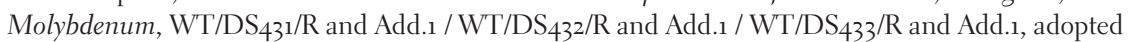
29 August 2014, upheld by Appellate Body Reports WT/DS431/AB/R / WT/DS432/AB/R / WT/DS433/ $\mathrm{AB} / \mathrm{R}, \mathrm{DSR} 2014 \mathrm{IV}$, at 1127 . 
"all measures of general application which pertain to electronic commerce" and "all measures relating to public telecommunications networks or services", while the other is on domestic regulation. The last draft article is particularly interesting, as it, in addition to incorporating GATS Article VI, also specifically states that "[n]othing in this Agreement shall be construed to affect any Member's right to conduct a content review for the purposes of achieving legitimate public policy objectives". Again, the inspiration for this clause comes from the China-Publications case. Even though China's right to conduct content review was explicitly affirmed by the Appellate Body in that case, China's inclusion of this draft clause indicates that it is not taking any chances and attaches high importance to its censorship regime, which is another non-negotiable item.

\section{The Third Submission}

Compared to the second submission, China's third submission, ${ }^{85}$ made on 20 September 2019, has fewer draft articles - eight instead of twelve - but at a greater length - six instead of five pages. This is because the draft articles are more detailed in the third submission, indicating that China has probably put more effort into drafting these articles.

With the exception of the last article, the third submission mainly focuses on trade facilitation measures. These include three articles on streamlining customs administration, such as transparency and non-discrimination of trade policy, paperless trading and various measures to enhance trade facilitation, including implementation of a trade facilitation agreement, advance electronic data for customs clearance, electronic payment of duties, bounded warehouse and free zones, regional distribution centres, and expedited clearance for low-risk cargo and collective clearance. Three other articles call on members to improve their e-commerce-related services commitments, such as online trade facilitating and supporting services like those provided by Alibaba, logistics services like those provided by SF Express and electronic payment services like those provided by Alipay. Together, they help to solve three common problems faced by developing countries when they try to develop e-commerce: lack of a good e-commerce platform, a slow or non-existent logistics network and the inability to transfer payments between buyers and sellers. Of course, all these are likely to be achieved with the help of Chinese firms, which are now the world leaders in providing e-commerce solutions on platform, logistics and payment. Even though such services are mainly provided online, they might need the physical presence of e-commerce-related personnel to set up, maintain and repair. Thus, another article suggests members facilitate the temporary entry and sojourn of such

85 WTO, Joint Statement on Electronic Commerce, Communication from China, INF/ECOM/40, 23 September 2019. 
personnel. This is similar to the GATS visa proposal by India, albeit further limiting the beneficiaries to e-commerce-related personnel.

The last draft article in the submission is on "Electronic Commerce-Related Network Equipment and Products". Ostensibly, it can be said to be related to trade facilitation in e-commerce, but it is quite obvious that such equipment and products are capable of much wider use in the telecom sector, especially in view of the expansive definition provided in the article, which covers "all hardware and related software and services that can be used to support transactions done by electronic means, including telecommunication network equipment, products, resources, and related services such as installation, trial operation, testing, optimization, maintenance and repair services and etc., and other related equipment, products, resources and related services". The article calls on members to not discriminate against "network equipment and products of any other Member", which are further elaborated in three successive substantive paragraphs to mean not to exclude such network equipment and products, not to prevent public telecommunications networks or their services suppliers from choosing them and not to "block the supply chains of electronic commerce-related network equipment and products, in particular those based on long-term commercial cooperation, including cutting or prohibiting the supply to enterprises of any other Member of necessary raw materials, components, parts, software, technologies and their updates for electronic commerce-related network equipment and products".

As this proposal was submitted after the widely reported exclusion of Huawei in the ${ }_{5} \mathrm{G}$ network in Europe and Australia, and the ban on the sales of chips and the licence of the Android system to Huawei by the USA, the inclusion of the article on network equipment and products is probably far from mere coincidence. It reflects China's attempt to fight what it perceives as "technology protectionism" using trade rules, which along with the "Made in China 2025" plan is another key component of China's quest for technological supremacy. But for two reasons, China might see its initiative thwarted.

First, this is more of a telecom issue, which is arguably beyond the scope of e-commerce negotiation. Even though telecommunication has been added as one of the focus groups of discussion, past experiences in GATS negotiations such as the Reference Paper have shown that the members are more concerned with services regulatory issues such as competitive safeguards, licensing and regulatory requirements rather than hardware-related issues. ${ }^{86}$ Instead, technical issues on hardware and software have traditionally been dealt with at the International Telecommunication Union (ITU). This is also confirmed by the recent discussions of the issue in the JSI, where several members noted either that "the JSI was

86 See H Gao, "Telecommunications Services: Reference Paper", in R. Wolfrum et al. (eds), Max Planck Commentary on World Trade Law, Volume VI: Trade in Services (Leiden, Martinus Nijhoff Publishers, 2008), at 718-747. 
not the appropriate forum to discuss this topic" or "some topics were more appropriate to be discussed at the ITU". ${ }^{8}$

Second, even if JSI participants agree to engage in discussions on the issue, it would not be hard for them to justify any restrictions they might introduce or maintain with the security exception, which, ironically, also features prominently in China's second submission discussed earlier, where China advocates broad leeway for members to take "any action which it considers necessary for the protection of its essential security interest”.

Interestingly, even though China addresses - albeit in a negative manner - the issues of data flow and localization in its first submission, neither the second nor the third submission contain language on these issues. Nor was the moratorium on customs duty mentioned.

\section{ACROSS THE GREAT WALL}

Initially reluctant to join the JSI negotiation on e-commerce over concerns about it being a US plot, China has finally jumped on the JSI bandwagon at its launch in Davos in January 2019 and emerged as one of the most active participants. Such a policy shift is the result of China's realization that it is important to enhance its rule-making power in e-commerce and cyberspace, as noted by President $\mathrm{Xi}$ in his speech at the 36 th Collective Study Session of the Politburo. ${ }^{88}$

Despite being a world leader in e-commerce, or in China's own words, "trade in goods facilitated by the internet", China's draconian approach to cybersecurity has made people question whether it would make a positive contribution to global e-commerce governance, with some even calling for "disqualifying" China from participation in the JSI negotiation. ${ }^{89}$ Indeed, as reviewed earlier in this chapter, while many of China's detailed proposals, especially those on trade facilitation and consumer protection, seem rather innocuous or even benevolent as they do offer good lessons for developing countries eager to catch the e-commerce train, its proposals on security exception and content review do raise concerns on whether China would be willing to accept the main demands of the USA and other Western countries; that is, free flow of information across border; free and open internet; and prohibition of localization requirements, forced technology transfer and transfer of source code. ${ }^{90}$

87 Joint Statement on Electronic Commerce, 11-14 February 2020, Facilitator's Reports, Seventh Negotiating Round, INF/ECOM/R/7, 25 February 2020 .

88 “习近平：加快推进网络信息技术自主创新 朝着建设网络强国目标不解努力 [Xi Jinping: Accelerate the Promotion of Indigenous Innovation on Internet Information Technology, Strive Unrelentingly Towards the Objective of Building the Internet Power]" (Xinhua News, 9 October 2016), https://perma.cc/S3Z9-33ZD.

$89 \quad$ N Cory, "Why China Should Be Disqualified from Participating in WTO Negotiations on Digital Trade Rules" (2019), https://perma.cc/AgLM-3SZT.

$9 \circ$ WTO, Work Program on Electronic Commerce, Non-paper from the United States, JOB/GC/94, 4 July 2016. Also affirmed in Joint Statement on Electronic Commerce, Communication from the United States, INF/ECOM/23, 26 April 2019. 
However, all these considerations do not necessarily have to spell the end of China's participation in the JSI, especially if one takes a closer look at the nuances of the contrasting positions between China and the West. Here I will illustrate the potential for compromises with a few key examples.

\section{A Free Flow of Information}

Many commentators, especially those with a technology or internet background, tend to believe that the free flow of data should be absolute; that is, it should apply to all data. While this could be a laudable ultimate goal, at present this is far from how the principle is understood in trade agreements. Take, for example, the relevant provisions in the Comprehensive and Progressive Agreement for TransPacific Partnership (CPTPP) and the United States-Mexico-Canada Agreement (USMCA), both of which are regarded as providing the "gold standard for digital trade", at least in the eyes of the USA, the main drafter of the rules..$^{91}$ Instead of calling for a blanket free flow of information, both agreements only require the parties to allow the cross-border transfer of information by electronic means "when this activity is for the conduct of the business of a covered person". ${ }^{22}$ This is entirely understandable because trade agreements, at the end of the day, are not human rights agreements. Instead, they are designed to facilitate crossborder trade, which means data flow is protected only when it contributes to the trade flow. Thus, to the extent that China does not wish to allow data flow for a specific type of service activity, it can simply carve out an exception for that specific sector. Indeed, this is probably why Google, despite the loud noises it made when it was forced to pull out of China in 2009, never successfully persuaded the USTR to bring a WTO case against China. As I analysed in the case study of the merits of such a case in 2011, such a complaint would be doomed as China has not made any commitments on the search engine services provided by Google. ${ }^{93}$

Moreover, both agreements also provide, in the same article, an exception clause that allows parties to adopt or maintain inconsistent measures "to achieve a legitimate public policy objective" so long as they do not constitute "arbitrary or unjustifiable discrimination or a disguised restriction on trade" and fulfil the necessity requirement. Thus, if needed, China could also invoke the exception clause to justify its data flow restrictions, as it did in the China-Publications case. Moreover, as shown by the case, the USA does not have a problem with the exception per se; instead, its main concern is that it is discriminatory and not necessary. 


\section{B Data Localization}

Another oft-mentioned concern is data localization, where people believed that China requires the localization of all data. Again, this is another misconception as the provision in question, Article 37 of China's Cyber Security Law, only requires local storage for "personal information and important data collected and generated by operators of critical information infrastructure from its operations within the people's Republic of China". ${ }^{94}$ Thus, there are important qualifiers on the types of data (only personal information and important data); types of operators (only operators of critical information infrastructure); and geographical scope (only data generated from its operations in China). Moreover, the final version of the law already improves previous drafts. For example, the first draft of the law applies the localization requirement to all such data generated by such operators from its operation all over the world, ${ }^{95}$ and the final text greatly reduces the impact by limiting the geographical scope to those generated within China.

Of course, the final provision on data localization is far from perfect for several reasons. First, in addition to the commonly used concept of "personal information", the law also includes "important data", a concept that has yet to be defined by Chinese law. Second is what constitutes "critical information infrastructure". Article 31 of the Cyber Security Law defines it as those in "important industries and fields such as public communications and information services, energy, transport, water conservancy, finance, public services and e-government affairs", as well as those "that will result in serious damage to state security, the national economy and the people's livelihood and public interest if it is destroyed, loses functions or encounters data leakage". Such a broad definition could potentially capture everything and is not really helpful, which is why the same Article also directed the State Council to develop the "specific scope of critical information infrastructure". In 2016, the Cyberspace Administration of China issued the National Network Security Inspection Operation Manual ${ }^{96}$ and the Guide on the Determination of Critical Information Infrastructure, ${ }^{97}$ which clarified the scope of critical information infrastructure by grouping them into three categories: websites, which includes the websites of government and party organizations, enterprises and public institutions, and news media; platforms, which includes internet service platforms for instant

94 “中华人民共和国网络安全法 [Cyber Security Law of the People’s Republic of China]”, 7 November 2016, https://perma.cc/NZ2C-ET2X.

95 Article 31 of the first draft dated 6 July 2015; see 网络安全法 (草案) 全文 [Cyber Security Law (Draft) Full Text], 6 July 2015, https://perma.cc/49LT-3ZKF.

${ }_{96}$ Central Leading Group on Cyber Security and Informatisation General Office, “国家网络安全检查 操作指南 [Network Security Coordination Bureau, National Network Security Inspection Operation Manual]", June 2016 (on file with author).

97 关键信息基础设施确定指南 (试行) [Guide on the Determination of Critical Information Infrastructure (Trial)], under 关于开展关键信息基础设施网络安全检查的通知 [Notice on Conducting Network Security Inspections of Key Information Infrastructure], Zhongwangban Fawen [2006] \#3, Annex 1, July 2016, https://perma.cc/E3PF-H6RD. 
messaging, online shopping, online payment, search engines, emails, online forums, maps and audio video; and production operations, which includes office and business systems, industrial control systems, big data centres, cloud computing and TV broadcasting systems. They also laid down three steps in determining the critical information infrastructure, which starts with the identification of the critical operation, then continues with the determination of the information system or industrial control system supporting such a critical operation, and concludes with the final determination based on the level of the critical operations' reliance on such systems and possible damages resulting from security breaches in these systems. More specifically, they listed eleven sectors, which include energy, finance, transportation, hydraulic, medical, environmental protection, industrial manufacturing, utilities, telecom and internet, radio and TV, and government agencies. The detailed criteria include both quantitative and qualitative criteria. For example, critical information infrastructure includes websites with a daily visitor count of more than 1 million people and platforms with more than 10 million registered users or more than 1 million daily active users, or a daily transaction value of 10 million RMB. On the other hand, even those that do not meet the quantitative criterion could be deemed to be critical information infrastructure if there are risks of security breaches that would lead to leakage of lots of sensitive information about firms or enterprises, or leakage of fundamental national data on geology, population and resources, seriously harming the image of the government or social order, or national security. The potentially wide reach of the criteria was well illustrated by the case of the BGI Group, which was fined by the Ministry of Science and Technology in October 2018 for exporting certain human genome information abroad via the Internet without authorization. ${ }^{98}$ Given the nature of their business, the BGI case could fall under the category of "leakage of fundamental national data on ... population", as mentioned earlier.

The last problem with China's data localization policy is that, according to Article 37, only the export of personal information and important data requires security review, while there is no such requirement for domestic use. This could be interpreted as discriminatory and arbitrary, and constitute disguised restrictions in international trade.

Of course, this does not mean that all hope is lost on a potential deal on data localization. Instead, as I explained in another article, ${ }^{99}$ the key to understanding China's data regulation is national security, which translates into the ability to maintain its censorship regime. So long as the Chinese regulators can continue to conduct content view and block foreign websites on security grounds, where the data is stored would be much less important. Actually, given the sophistication of the Great Firewall, data stored in offshore servers would be easier to block and filter.

\footnotetext{
$9^{8}$ S An, “数据出境如何“安检 [How to Conduct a 'Safety Check' for Exporting Data]” (Zhihu), https:// perma.cc/V6VZ-P8TM.

99 Gao, note 6 above.
} 
In this regard, it is instructive to study the evolution of the US approach on data localization for financial services. In the TPP negotiation, the USA carved out the entire financial services sector from the scope of its e-commerce chapter, including prohibition of data localization requirements. ${ }^{100}$ In the new USMCA, however, the USA explicitly brought over the ban to the financial services sector by stating that data localization should not be required "so long as the Party's financial regulatory authorities, for regulatory and supervisory purposes, have immediate, direct, complete, and ongoing access to information processed or stored on computing facilities that the covered person uses or locates outside the Party's territory". ${ }^{101}$ If such language can successfully overcome the grave concerns of the US Federal Reserve, then the Chinese regulators would probably also have less reason to insist on local storage instead of having "immediate, direct, complete, and ongoing access to information processed or stored on computing facilities outside the Party's territory". ${ }^{102}$

To conclude, while China's participation in the JSI would make the negotiations difficult, it also provides an opportunity to understand better the policy rationale of China's data regulation, so that avenues for convergence and compromise can be found.

\section{Postscript}

When I first raised the possibility of China agreeing to provisions on the free flow of data and a ban on data localization in trade agreements at the Biennial Conference of the Asian International Economic Law Network hosted by Prof. Shin-yi Peng in October 2019, few if any scholars took the idea seriously. However, barely a year later, my prediction was confirmed when China signed the RCEP, which includes provisions disallowing its members from "requir[ing] a covered person to use or locate computing facilities in that Party's territory as a condition for conducting business in that Party's territory" ${ }^{103}$ or "prevent[ing] cross-border transfer of information by electronic means where such activity is for the conduct of the business of a covered person". ${ }^{104}$ While both Articles are subject to exceptions allowing a Party to adopt or maintain measures that such a Party considers necessary "to achieve a legitimate public policy objective" or "for the protection of its essential security interests", the very fact that China is willing to accept such obligations is encouraging. Moreover, unlike four of the fifteen RCEP members, ${ }^{105}$ China did not seek

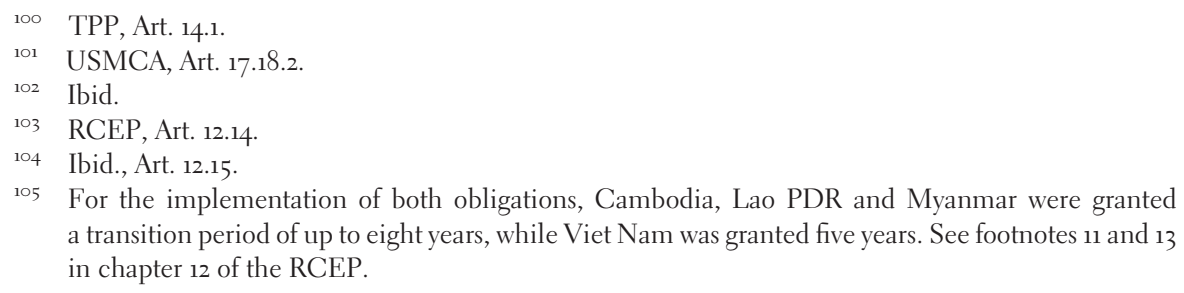


any transition period for both obligations to take effect. While the chapter on e-commerce is not subject to the normal dispute settlement procedure under the RCEP, the importance China attaches to the RCEP and the peer pressure under the consultation and Joint Committee procedures could provide some incentive for China to implement the obligations in good faith. This is partially confirmed by MOFCOM, which announced in March 2021 that China has ratified the RCEP and finished the preparatory work to implement 613 of the total 701 obligations China has assumed under the RCEP, with the rest ready to implement when the agreement comes into effect. ${ }^{106}$ Presumably, the 701 obligations would include the twin obligations on free flow of data and prohibition of data localization requirements.

If we can learn anything from the RCEP, it is that actively engaging China in e-commerce negotiations is much better than leaving China in its own cyber enclave. The Internet was built to transcend walls. International negotiations on the Internet and e-commerce should also help people reach across walls, no matter how great they might be.

106 “积极推动RCEP生效, 我国已完成协定核准工作 [Actively Pushing for the Coming into Force of the RCEP, China Has Finished the Ratification of the Agreement]" (People's Daily, 26 March 2021), http://paper.people.com.cn/rmrb/html/2021-03/26/nw.D110ooorenmrb_20210326_6-o2.htm. 